\title{
The relationship between the male and female language performance and the level of anxiety among Iranian EFL students
}

\author{
Abusaied Janfaza \\ Department of Foreign Languages, Payam-E-Noor University (PNU), Jiroft, Iran \\ E-mail:s_janfaza@hotmail.com \\ Yousof Rezaei \\ Department of Language and Literature, Larestan Branch \\ Islamic Azad University, Larestan, Iran \\ Email: rezaeiyousof@gmail.com \\ Afshin Soori \\ Department of Language and Literature, Larestan Branch \\ Islamic Azad University, Larestan, Iran \\ E-mail: afshin_soori@yahoo.com
}

\begin{abstract}
This study tries to investigate the relationship between the male and female language performance and the level of anxiety among Iranian EFL students. The participants of the current study were 26 Iranian EFL students studying English in Islamic Azad University, Larestan, Iran who were selected in terms of the administering of an Oxford Placement Test. Then, the students were given The Foreign Language Classroom Anxiety Scale. Finally, they were given an English class test which consisted of 40 multiple-choice items. The researcher calculated the correlation between the Foreign Language Classroom Anxiety Scale and the performance of both Iranian male and female students on English Class test. The findings indicated that there was a negative correlation between the level of anxiety and the students' performance on English Class Test scores. Moreover, Iranian male students were more anxious in learning English than female students.
\end{abstract}

Keywords: Anxiety; Performance in English; EFL students; Gender.

\section{Council for Innovative Research}

Peer Review Research Publishing System

\section{Journal: Journal of Advances in Linguistics}

\author{
Vol 4, No. 3 \\ editor@cirjal.com \\ www.cirjal.com
}




\section{Introduction}

One of the cumbersome tasks for Iranian students is foreign language learning, and the foreign language situations may be susceptible to a variety of affective-arousal elements which may affect students' learning a foreign language. Brown (2000) relates these elements to some affective domain in second or foreign language learning which includes different factors like self-esteem, motivation, and anxiety. It seems that these socio-culturally-factors may affect differently in different cultures. "The nature of these variables centrally revolves around some context-sensitive feelings and emotions discerned by language learners across various contexts" (Brown, 2000 as cited in Mahmoodzadeh, 20013). Foreign Language Anxiety is an important variable which lies in the heat of affective domain which is responsible for improving language learning among EFL learners in an educational context (Horwitz, 2001; Mclntyre, 1995). Shrestha (2009) believes that to make the teaching context ecologically sound, teachers should be so sensitive to teaching anxiety which is an important element in the language classroom. Considering the importance of this variable, it is interesting to mention most of language learners (with different language backgrounds) have experiences of perceiving some anxiety in language classrooms (Worde, 1998), even advanced language learners have some anxiety in language classrooms (Horwitz, 2000). Thus, many students are afraid of being unsuccessful in language learning. Some students become anxious, when they are unable to transfer their messages. As a result, anxiety may influence on the students' learning and even using the second language (Brown, 2001). However, as Horwitz (2000) states this feeling is natural among the language learners. Several researchers (e.g. Awan, Azher, Anwar \& Naz, 2010) refer to the fundamental role of anxiety in language learning. To Sparks \& Ganschow (2007) there is a negative correlation between anxiety and language performance.

Language anxiety has been defined as a "distinct complex of self-perceptions, beliefs, feelings, and behaviors related to classroom language learning arising from the uniqueness of the language learning process" (Horwitz, Horwitz and Cope 1991,p. 31). Horwitz, Horwitz and Cope (1991) believe that "research has neither adequately defined foreign language anxiety nor described its specific effects on foreign language learning" (p. 125).

The anxiety in foreign language education has attracted the researchers' attentions. Some previous studies (e.g. Granschow et al., 1994; Gregersen, 2005; Seller, 2000; Young, 1990) in foreign language anxiety have been investigated from the learners' perspectives. Additionally, in some other studies (e.g. Kota, 2005; Young, 1992) foreign language anxiety has been explored from other perspectives like teachers' perspectives. According to Kim \& Kim and Kim (2004), non-native teachers also have some degree of foreign language anxiety. However, considering this issue is very important that "teachers get engaged in language teaching, they are non-native learners whose language is not perfect, such lack of confidence can inhibit a teacher's ability to effectively present the target language, interact with students and serve as a positive role model as a language learner" (Horwitz, 1996, p. 366). Foreign language teaching anxiety is an issue that has been considered recently. To this end, some general sources which are responsible for teaching anxiety are "English proficiency, lack of confidence, class management, insufficient class preparation, teaching procedures, fear of negative evaluation, and lack of teaching experience" (Mahmoodzadeh, 20013,p.62)

Cample and Shaw (1994) refer to the meaningful relationship between gender and anxiety in foreign language learning. The findings of their study revealed that male more than female students were anxious in learning foreign language. The results of another study by Misre and Mcken (2000) showed a gender difference in anxiety and stress. Some Iranian researchers (e.g. Merci, 2012) investigated the relationship between gender and anxiety. He found that Iranian female learners were more anxious than male language learners. It seems that the findings of the previous studies are contrast with a study by Mills, Pajares, \& Herron (2006) who stated that there was a positive relationship between anxiety and male and female performance. The findings of another study confirmed the significant role of foreign language anxiety.

There are a few researches to investigate the relationship between anxiety and the students' performance. To this end, the present study sheds light the relationship between the male and female language performance and the level of anxiety among Iranian EFL students. Based on the purpose of the study, the research question is as follows:

1. Do Iranian EFL male and female students have the same level of anxiety?

2. Is there any relationship between the male and female language performance and the level of anxiety among Iranian EFL students?

\section{Methodology}

\section{Participants}

The participants of the present study were 26 Iranian EFL students studying English in Islamic Azad University, Larestan, Iran. These students were selected from among 50 students. The selection of the students was based on the administering of an Oxford Placement Test. The selected students were assigned into two equal groups of 13 students in each group. One group included 13 male students and the second group consisted of 13 female students. The students age ranged from 18 to 24 years old.

\section{Instruments and Procedure}

The researcher of this study used different instruments. The instruments used were an Oxford Placement test, and a Foreign Language Anxiety Scale. The Oxford Placement Test contained two parts as the listening section and the grammar section. The test included 100 multiple-choice items. The researcher used this test to be sure of homogeneity among the participants prior to the starting of the study. This test was a standard test and the reliability and validity of the test had been proved. 
The Foreign Language anxiety scale which was used by the researcher was one taken from Horwitz et al., (1986). It included 33 items which was able to evaluate anxiety in a language classroom. The main purpose of the Foreign Language Anxiety Scale was to measure the students' anxiety. As a result, this scale can assess the students' anxiety related to communication comprehension, and test anxiety (Horwitz et al., 1991). The reliability of the test was 0.94 which had been measured by Aida (1994).

The researcher administered a multiple-choice test. The content of the test was based on what the students had learned during the term. It included fifty grammar, vocabulary, and listening items.

\section{Results and Discussion}

The researcher used Foreign Language Classroom Anxiety Scale to measure the level of anxiety among the participants. Horwitz et al., (1986) consider 33 to 165 as a possible score range for the scale. The outcome of Foreign Language Classroom Anxiety Scale indicated the level of anxiety for the students was a range from 64 to 109 . The result also showed the mean score of 88.57 for the male students and 83.86 for the female students. The standard deviation for the male students was 13.45 , and it was 7.38 for the female students. The classification of scores showed that none of the students had a low level of anxiety because none of the students had a score between 33 and66. Moreover, no students had a score between 133 and 165 which is regarded as quite anxious.

To identify the probable significant difference between males and females in the level of anxiety, an independent sample t-test was run.

Table 1: Independent Samples t-test for Equality of Means

\begin{tabular}{llllccc}
\hline $\mathrm{F}$ & Sig. & $\mathrm{t}$ & $\mathrm{df}$ & Sig. & Mean Difference & Std. Difference Error \\
7.49 & .006 & 1.181 & 44 & .247 & 5.38 & 4.035 \\
\hline
\end{tabular}

As depicted in Table 1, no significant difference was seen between male and female students with regard to anxiety, and the $p$ value was larger than the significance level $(.247>.05)$.

To answer the second research question, a multiple choice test with 40 items were given to all the students. To estimate the degree of correlation between the students' anxiety and the students' scores on English Class Test, the male and female performance on the multiple choice test were correlated with Foreign Language Classroom Anxiety Scale. As it can be seen, Table 2 indicates correlational analysis between Anxiety Scores and English Class Test Scores.

Table 2: Correlational Analysis between Anxiety Scores and English Class Test Scores

\begin{tabular}{ccc}
\hline Variables & Groups & \\
\hline & Pearson Correlation & Sig. (2-tailed) \\
\hline Scores/Anxiety & -0.821 & .000 \\
\hline
\end{tabular}

As shown in Table2, the results of Pearson correlation reveals high degree of correlation between Anxiety Scores and English Class Test Scores, and it is considered significant $(r=-0.821, p=0.000)$. In addition, another correlation was done to identify the amount of correlation for male and female students separately. Table 3 presents the correlation for male group, and Table 4 indicates those of the female group.

Table 3: Correlation between Anxiety and Males' Test Scores

\begin{tabular}{|c|c|c|}
\hline Variables & Groups & \\
\hline & Pearson Correlation & Sig. (2-tailed) \\
\hline Males' Anxiety & Scores/males & .000 \\
\hline
\end{tabular}

As depicted in Table 3, there is a high amount of correlation $(r=-.903)$, and it is significant at probability level of 0.05 . These two variables are negatively correlated. Therefore, the correlation is negative. In other words, whatever the level of anxiety is higher, the students' performance on a test is lower. Table 4 reveals the correlation for the female students. 
Table 4: Correlation between Anxiety and Females' Test Scores

\begin{tabular}{|c|c|c|}
\hline Variables & Groups & \\
\hline & Pearson Correlation & Sig. (2-tailed) \\
\hline Females' Anxiety & Scores/ females $\quad-0.827$ & .000 \\
\hline
\end{tabular}

As it can be seen in Table 4, the is a high amount of correlation $(r=-.827)$, and it is significant at probability level of 0.05 . These two variables are also negatively correlated.

It seems that the findings of the study are in line with the results of Kafi Anaraki et al., (2014), but not in line with the findings of another study by Mersi (2012) who came to the conclusion that affective factors can influence females' performance than males' performance. Merci's results showed a strong correlation between females' performance and the Foreign Language Classroom Anxiety Scale. But this correlation was weak for male students. In addition, the findings of the current study cannot be in line with a study by Matsuda and Gobel (2004) who believed that gender plays a significant role in the classroom anxiety. Furthermore, in their study Yamat and Shirani (2012) found that in comparison to females, males are more anxious in tests and communication in language classrooms. Finally, the findings of the present study indicated that when learning English as a foreign language Iranian male students in comparison to females had more anxiety experiences. Thus, the findings are in contradiction with those of Arnaiz and Guillén's (2012) who claimed that females had more anxiety experiences than males. They believe that "factors like fear of speaking English without preparation, fear of making correction, fear of making mistakes and being stopped by the teacher, fear of losing mark, fear of calling for answering questions, afraid of not being ready for answering question, and fear of making mistakes in front of their teachers had become the primary sources of anxiety" (Arnaiz and Guillén's 2012 as cited in Kafi Anaraki et al., 2014,p. 35). Peer influence was another factor which was considered by Bekleyen (2004) that can influence on the anxiety levels. However, an anxiety provoking factor for the students is speaking in front of peers.

\section{Conclusion}

The main aim of the present study was to find out whether the Iranian male and female students are different in terms of anxiety in a language classroom, and whether there was a the relationship between level of anxiety and the Iranian male and female language performance. The findings indicated that the male anxiety level was higher than that of females. In addition, there was a negative correlation between the level of anxiety and the students' performance on English Class Test scores. Perhaps the current findings are changeable with a larger sample of participants. Regarding the findings, teachers should encourage the students to be active in the classroom and not be afraid of being unsuccessful in language learning. Moreover, to decrease the amount of anxiety among the students, the students should be asked to be volunteers to answer the questions in a language classroom.

\section{References}

Aida, Y. (1994). Examination of Horwitz, Horwitz, and Cope's construct of foreign language anxiety: The case of students of Japanese. The Modern Language Journal, 78(2), 155-168.

Arniaz, P., \& Guillén, F. (2012). Foreign language anxiety in a Spanish university setting: Interpersonal differences. Revista de Psicodidáctica, 17(1), 5-26.

Awan, R.N., Azher, M., Anwar, M.N., \& Naz, A. (2010). An investigation of foreign language classroom anxiety and its relationship with students' achievement. Journal of College Teaching and Learning, 7(11), 33-40.

Bekleyen, N. (2004). The influence of teachers and peers on foreign language classroom anxiety. Dil Dergisi (Language Journal), 123, 49-660.

Brown, H. D. (2000). Principle of Language Learning and Teaching (4th ed.). Pearson Education: Longman.

Ganschow, L. (2007). Is the foreign language classroom anxiety scale measuring Sparks, R. L., \& anxiety or language skills? Foreign Language Annals, 40, 261-287.

Ganschow, L., \& Sparks, R. L. (1996). Anxiety about foreign language learning among high school women. The Modern Language Journal, 80, 199-212.

Gregersen, T. S. (2005). Non verbal cues: Clues to the detection of foreign language anxiety. Foreign Language Annuals, 38, 388-400.

Horwitz, E. K. (1996). Even teachers get the blues: Recognizing and alleviating non-native teachers' feelings of foreign language anxiety. Foreign Language Annals, 29, 365-372.

Horwitz, E. K. (2000). It ain't over til it's over: On foreign language anxiety, first language deficits, and the confounding of variables. The Modern Language Journal, 84, 256-259.

Horwitz, E. K. (2001). “Language anxiety and achievement”, in Annual Review of Applied Linguistics, $21: 112-$ 126. 
Horwitz, E. K., Horwitz, M. B, \& Cope, J. A. (1986). "Foreign Language Classroom Anxiety". Modern Language Journal, 70(2), 125-132.

Horwitz, E. K., Horwitz, M. B., \& Cope, J. (1991). Foreign language classroom anxiety. In E. K. Horwitz \& D. J. Young (Eds.), Language anxiety: From theory and research to classroom implications (pp. 27-36). Upper Saddle River, NJ: Prentice Hall.

Kafi Anaraki, F., Afghari, A. \& Koosha, M. (2014). An Investigation of the Relationship between Teacherinduced Anxiety and Iranian Male and Female EFL Learners' Performance in English, 6 (1), 30-37.

Kim, S. Y., \& Kim, J. H. (2004). When the learner becomes a teacher: Foreign language teaching anxiety as an occupational hazard. English Teaching, 59(1), 165-186.

Kota, O. (2005). Language anxiety from the teacher's perspective: Interviews with seven experienced ESL/EFL teachers. Journal of Language Learning, 3(1), 230-249.

Maclntyre, P.D.(1995). How does anxiety affect second language learning? A reply to Sparks and Ganschow. Retrieved December, 3, 2010 from www.jstor.org/stable/329395

Mahmoodzadeh, M. (2013). Investigating foreign language anxiety in Iranian classrooms: The effect of gender. International Journal of Research Studies in Language Learning, 2(1), 61-70.

Matsuda, S. \& Goble, P. (2004). Anxiety and predictors of performance in the foreign language classroom. System, 32, 21-36.

Mersi, F. (2012). The relationship between gender and Iranian EFL learners' foreign language classroom anxiety (FLCA). International journal of Academic Research in Business and Social Science. 2(6).

Mills, N., Pajares, F., \& Herron, C. (2006). A reevaluation of the role of anxiety: selfefficacy, anxiety, and their relation to reading and listening proficiency. Foreign Language Annals, 39(2), 276-295.

Misra, R., \& Mecken, H. L. (2000). College students' academic stress and its relation to their anxiety, time management, and leisure satisfaction. American Journal of Health Studies, 16(1), 41-55.

Sellers, V. D. (2000). Anxiety and reading comprehension in Spanish as a foreign language. Foreign Language Annals, 33, 512-520.

Shrestha, P. (2009). Foreign language teaching anxiety. Nelta Choutari, April.

Wörde, R. V. (1998). An investigation of students' perspectives on anxiety and speaking. Foreign language Annals, 23(6), 539-553.

Yamat, H., \& Shirani Bidabadi, F. (2012). English language learning anxiety among Iranian EFL freshman university learners. Research Journal of Applied Sciences, 7, 413-420. 